\title{
Human Herpesvirus-6 corneal Endotheliitis after intravitreal injection of Ranibizumab
}

\author{
Masahiro Onda', Yusuke Niimi ${ }^{1}$, Kenji Ozawa' ${ }^{1}$ Ikumi Shiraki ${ }^{1}$, Kiyofumi Mochizuki', Tetsuya Yamamoto', \\ Sunao Sugita ${ }^{2}$ and Kyoko Ishida ${ }^{3^{*}}$ (D)
}

\begin{abstract}
Background: To report the first case of human herpesvirus-6 (HHV-6) corneal endotheliitis that developed after intravitreal ranibizumab injections.

Case presentation: A 63-year-old man with a medical history of diabetes and systemic steroid treatment for bullous pemphigoid had been receiving intravitreal injections of ranibizumab in the left eye for 2 years according to a Pro Re Nata treatment regimen for macular edema associated with branch retinal vein occlusion. Twenty days after the last injection, the patient presented with pain and decreased visual acuity in his left eye. His best corrected visual acuity in the left eye was 2/200, and intraocular pressure was $45 \mathrm{mmHg}$ with edema of the central stromal cornea, mild conjunctival injection, intermediate keratic precipitates, and mild anterior chamber reaction. HHV-6 DNA was detected in the aqueous humor using multiplex strip polymerase chain reaction, and it was identified as variant A, HHV-6A. A diagnosis of HHV-6A-associated corneal endotheliitis was made. Oral valganciclovir and topical ganciclovir therapy was initiated with good resolution of all symptoms and signs.

Conclusions: HHV-6A can be a possible complication of intravitreal ranibizumab therapy. To the best of our knowledge, this is the first reported case of HHV-6A corneal endotheliitis following intravitreal ranibizumab injection.
\end{abstract}

Keywords: Human herpesvirus-6, Corneal endotheliitis, Intravitreal injection, Ranibizumab

\section{Introduction}

Human herpesvirus-6 (HHV-6) is a member of the HHV family and has been subtyped into two variants, variant A (HHV-6A) and variant B (HHV-6B) [1]. The seroprevalence of HHV-6 in the adult population approaches over 90\% [2]. In the United States, certain parts of Europe, and Japan, HHV-6B is the predominant cause of childhood HHV-6 infection [3]. In these regions, primary HHV-6B infection typically occurs by the age of 2 years, and it is the etiological cause of roseola infantum, also known as exanthema subitum [3]. Like all herpesviruses, HHV-6 establishes life-long latency in human hosts, and reactivation of a latent HHV-6 infection can cause serious complications, especially in immunocompromised patients [4]. In spite of our knowledge of HHV-6B, diseases associated specifically with HHV-6A have not yet been identified,

\footnotetext{
* Correspondence: kyoko.ish@gmail.com

${ }^{3}$ Department of Ophthalmology, Toho University Ohashi Medical Center,

2-22-36, Ohashi, Meguro-ku, Tokyo 153-8515, Japan

Full list of author information is available at the end of the article
}

and intraocular inflammation caused by HHV-6A has been described only in a small number of cases [3, 5-9].

Intravitreal injection of anti-vascular endothelial growth factor (anti-VEGF) agents has revolutionized the treatment of common retinal disease. Their increased use, however, has led to an increase in ocular post-injection and class-associated adverse drug events [10, 11]. Although rare, serious sight-threatening complications from intravitreal injection can include elevated intraocular pressure (IOP), keratitis, uveitis, cataract, retinal detachment, and endophthalmitis.

In the present study, we describe a rare case of an immunocompromised patient who developed corneal endotheliitis after intravitreal injection with the antiVEGF agent ranibizumab. Genomic HHV-6A DNA was detected in the aqueous humor of this patient by multiplex strip polymerase chain reaction (PCR). To our knowledge, HHV-6 corneal endotheliitis after intravitreal ranibizumab injection has not been previously reported.

(c) The Author(s). 2019 Open Access This article is distributed under the terms of the Creative Commons Attribution 4.0 International License (http://creativecommons.org/licenses/by/4.0/), which permits unrestricted use, distribution, and reproduction in any medium, provided you give appropriate credit to the original author(s) and the source, provide a link to the Creative Commons license, and indicate if changes were made. The Creative Commons Public Domain Dedication waiver (http://creativecommons.org/publicdomain/zero/1.0/) applies to the data made available in this article, unless otherwise stated. 


\section{Case presentation}

A 63-year-old Japanese man with a medical history of diabetes for 7 years, Fahr's disease for 4 years, and systemic steroid use for bullous pemphigoid for 2 years had been receiving intravitreal injections of ranibizumab in the left eye for 2 years according to a Pro Re Nata regimen (PRN) for macular edema associated with branch retinal vein occlusion. For his diabetes, the patient had been taking an oral anti-diabetic drug, miglitol, $50 \mathrm{mg}, 3$ times daily. His steroid therapy for bullous pemphigoid had begun with prednisolone at $20 \mathrm{mg} /$ day, had gradually tapered off, and continued at $5 \mathrm{mg} /$ day for the past 6 months. Twenty days after the last injection, the patient presented with a 1-week duration of left eye pain. Upon examination, his best corrected visual acuity (BCVA) was 20/15 in the right eye (OD) and 20/200 in the left eye (OS), and IOP was $19 \mathrm{mmHg}$ OD and 45 $\mathrm{mmHg}$ OS. Slit-lamp examination of the left eye revealed mild edema of the central cornea with mild conjunctival injection, intermediate keratic precipitates (KP), mild anterior chamber reaction, and incipient cataract. Coinshaped lesions, linear $\mathrm{KP}$, and iris atrophy were not present (Fig. 1). Dilated funduscopic examination of the left eye showed macular edema with hard retinal exudates secondary to a branch retinal vein occlusion. The patient's right eye was completely normal. Endothelial cell density was 2719 cells $/ \mathrm{mm}^{2}$ OD and 1733 cells $/ \mathrm{mm}^{2}$ OS Additional file 1.

Laboratory tests including blood cell count, leucocytes, $\mathrm{C}$-reactive protein, and angiotensin-converting enzyme were all essentially normal. Serologic tests were negative for syphilis, human immunodeficiency virus, and human T-cell leukemia virus type 1 (HTLV-1). The results

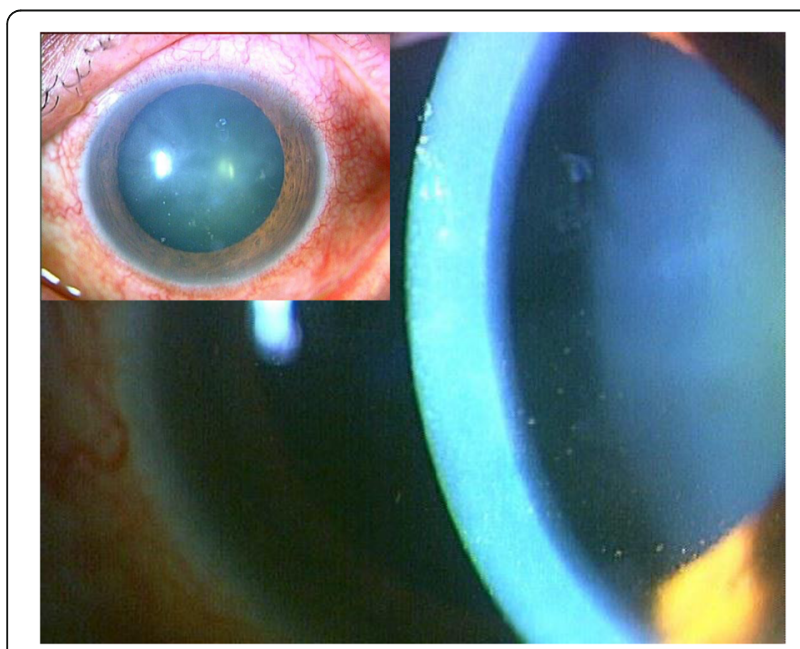

Fig. 1 External photograph of the left eye of the patient. This photograph was taken upon initial examination showing edema of the central cornea with mild conjunctival injection (insert) and mild anterior chamber reaction with intermediate keratic precipitates of serologic testing for HHV, herpes simplex virus (HSV), varicella zoster virus (VZV), cytomegalovirus (CMV), and Epstein-Barr virus (EBV) were positive. Based on the patient's ocular manifestations, bacterial or viral infection was suspected. Multiplex strip PCR, which can detect 24 common ocular infectious disease pathogens [12], was performed on biopsied aqueous humor. Results showed that genomic DNA of HHV- 6 was present. The 23 other pathogens, e.g., HSV type 1 and 2, VZV, EBV, CMV, HHV-7, HHV-8, bacterial 16s ribosomal RNA (rRNA), and fungal 28s rRNA were however not present. The concentration of HHV-6 DNA was $3.72 \times 10^{3}$ copies/ $\mathrm{mL}$, and the PCR product was specific for the HHV-6A variant sequence. Anti-HHV-6 IgG antibodies in blood samples were positive (40 times) and anti-HHV-6 IgM antibodies were negative ( $<10$ times).

These results led us to make the diagnosis of corneal endotheliitis with anterior uveitis related to an HHV-6 infection. We began treating the patient with $900 \mathrm{mg}$ of oral valganciclovir twice daily, as well as topical $1 \%$ ganciclovir and $0.1 \%$ betamethasone 4 times per day, without discontinuation of systemic steroids. Topical antiglaucoma agents ( $1 \%$ brinzolamide twice daily and $0.004 \%$ travoprost once per day) were also prescribed. Four weeks after the initiation of therapy, the copy number of HHV-6 DNA in the aqueous humor had decreased to $5.80 \times 10^{2}$ copies $/ \mathrm{mL}$. Six weeks later, the corneal edema and KPs were completely resolved. Therefore, oral valganciclovir and topical anti-glaucoma agents were discontinued. Topical ganciclovir with topical steroids was continued for 8 more months. The patient's BCVA improved to 20/80, the same level as before the episode of corneal endotheliitis, and IOP decreased to $18 \mathrm{mmHg}$ OS without anti-glaucoma agents. At the patient's one-year follow-up examination, endothelial cell density was 2786 cells/ $\mathrm{mm}^{2}$ OD and 2545 cells $/ \mathrm{mm}^{2}$ OS Additional file 2, and the eye was essentially normal without recurrences of corneal endotheliitis and anterior uveitis.

This study was approved by the Institutional Ethics Committee, Medical Review Board of Gifu University Graduate School of Medicine, and it adheres to the tenets of the Declaration of Helsinki. Informed consent was obtained from the patient.

\section{Discussion and conclusions}

The use of anti-VEGF is often included in current standard care for age-related macular degeneration, diabetic retinopathy, and retinal vein occlusion. Complications from intravitreal anti-VEGF administration can be attributed to the injection procedure or drug effects $[10,11]$. Activation of the virus after intravitreal anti-VEGF administration is rare, and there have been only two reports of herpetic epithelial keratitis after intravitreal bevacizumab injection $[13,14]$. These reports 
described a 63-year-old diabetic man who developed HSV epithelial keratitis [13] and a 66-year-old diabetic man with bilateral HSV keratitis following intravitreal bevacizumab injection [14]. To the best of our knowledge, however, there have been no reports of HHV-6 ocular infection following anti-VEGF therapy. HHV-6 infection almost always occurs in children before age 2 [3], and it can latently reside in cells of the lymphoid and myeloid lineage [15-17]. Various stressors have been implicated in herpetic activation including aging, stress, trauma, surgery, and immunosuppressive diseases $[13,14]$. Stressors such as these may reduce the body's cell-mediated virus-specific immune response. Our rare case may have been due to the combination of multiple factors. Immunocompromised status due to steroid treatment of bullous pemphigoid and diabetes mellitus, the periodic stress from injections, or the injection itself may have triggered the reactivation of HHV-6.

Intraocular inflammation associated with HHV-6 infection has been reported in cases without anti-VEGF injection. Table 1 [5-9, 18-29] summarizes the clinical manifestations of these reported cases. HHV-6 may cause ocular inflammation with optic neuropathy, optic vasculitis, and uveitis (Table 1). The first reported case was of an 11-year-old girl with unilateral chronic uveitis. Diagnosis was made in 1993 by detection of antiHHV-6 IgM and anti-HHV-6 IgG antibodies in a blood sample [18]. Oberacher-Velten et al. described a middleaged male patient with juvenile diabetes and bilateral optic neuropathy [19]. Aside from these two cases, diagnosis was made using PCR. HHV-6 has been subtyped into two variants: variant $\mathrm{A}(\mathrm{HHV}-6 \mathrm{~A})$ and variant $\mathrm{B}(\mathrm{HHV}-6 \mathrm{~B})$ [1]. HHV-6A has a greater predilection for neural cells than HHV-6B [30], but it is less often associated with disease than HHV-6B is [7]. Among the reported cases of intraocular inflammation with $\mathrm{HHV}$, virus subtype was identified in 6 cases as HHV-6A [5-9] and the current study] and in 9 cases as HHV-6B [7, 8, 21, 22]. In 4 of 6 cases of HHV-6A infection, however, Toxocara canis, CMV, and EBV were detected simultaneously [5, 7-9]. HHV-6 is closely related to CMV infection [7, 8, 27]. Yokogawa et al. found DNA of both CMV and HHV-6 in the aqueous humor of a 67-year-old man with unilateral corneal endotheliitis and a history of systemic steroid use for rheumatoid arthritis [27]. Cohen et al. tested vitreous fluid in 101 patients for HHV-6A, HHV-6B, and HHV-7 DNA by PCR, and HHV-6A DNA (4950 copies per $\mathrm{mL}$ ) was detected in the vitreous fluid of one patient with CMV retinitis [7]. Another report described a 71-year-old woman with unilateral necrotic retinitis who had DNA of both CMV and HHV-6 in a vitreous sample [8]. Although HHV-6 reactivation frequently accompanies CMV reactivation, the presence of HHV-6A DNA in the eye may merely reflect the immunocompromised state of the patient [7]. HHV-6 can latently reside in cells of the lymphoid and myeloid lineage, and thus it is possible that it could enter the inflamed eye via immune cells, similar to EBV and HIV [8, 31-33]. Sugita et al. [8] reported 8 cases of HHV-related ocular inflammation, and in 7 of these, other infectious agents were present (Toxocara canis, HSV-1, CMV, and 3 cases of bacterial infection). Thus, HHV-6 DNA in circulating $\mathrm{T}$ cells, monocytes, and leukocytes may have been carried to the eyes via inflammatory cells as a result of destruction of the blood-retina barrier [8]. However, we were only able to detect genomic HHV-6 DNA in the aqueous humor of our patient, not DNA from the other 23 pathogens, e.g., HSV type 1 and 2, VZV, EBV, CMV, HHV-7, HHV-8, bacterial 16s ribosomal RNA (rRNA), and fungal 28s rRNA,. Furthermore, the copy number of HHV-6 DNA in the aqueous humor decreased with anti-HHV treatment. Qavi et al. found that HHV-6 was capable of infecting corneal epithelial cells in vitro, causing morphological changes similar to those caused by other human herpes viruses [34]. Significant corneal endothelial cell density changes observed in our case may have been caused by corneal endotheliitis with mild edema of the central cornea, intermediate KP, and mild anterior chamber reaction. Thus, HHV- 6 could be one of the causative agents of corneal endotheliitis.

Aside from the cases of other suspicious ocular infections, HHV- 6 alone was detected in 11 cases: HHV-6A in 2 cases [6] and the current study, HHV-6B in 3 cases $[7,8,21]$, and HHV-6 in 6 cases [18-20, 23, 25, 29]. Among these cases, 4 were immunocompromised patients, 5 were immunocompetent, and detailed information from one patient was not available. Four of these 10 cases, from which patient information was available, were females, and 6 were males. Six cases were unilateral, and 4 were bilateral. Patients' ages ranged from 1 to 81 years, and the average age was 39.8. It is possible that differences in clinical presentation can be related to infection by the different viral variations [29]. With HHV-6A intraocular infection, only 2 cases (our case and Maslin's case [6]) reported infection of HHV-6A DNA with no other pathogens present. Both Maslin's case [6] and ours were elderly men with immunocompromised statuses.

Of the 13 cases $[5,6,9,19-23,25,27-29]$, and the current study which reported on prognosis, 11 (85\%) saw improvements following treatment (10 cases had anti-viral therapy; 1 had vitrectomy). A 1-year-old girl manifesting unilateral central retinal vein occlusion in one eye with exanthema subitum later experienced optic disc and fundus atrophy with unmeasurable BCVA [20]. A case of uveitis with optic neuritis in a healthy, elderly male patient resulted in a measured BCVA of 10/20 [25]. 
Onda et al. BMC Ophthalmology

(2019) 19:19

Page 4 of 7

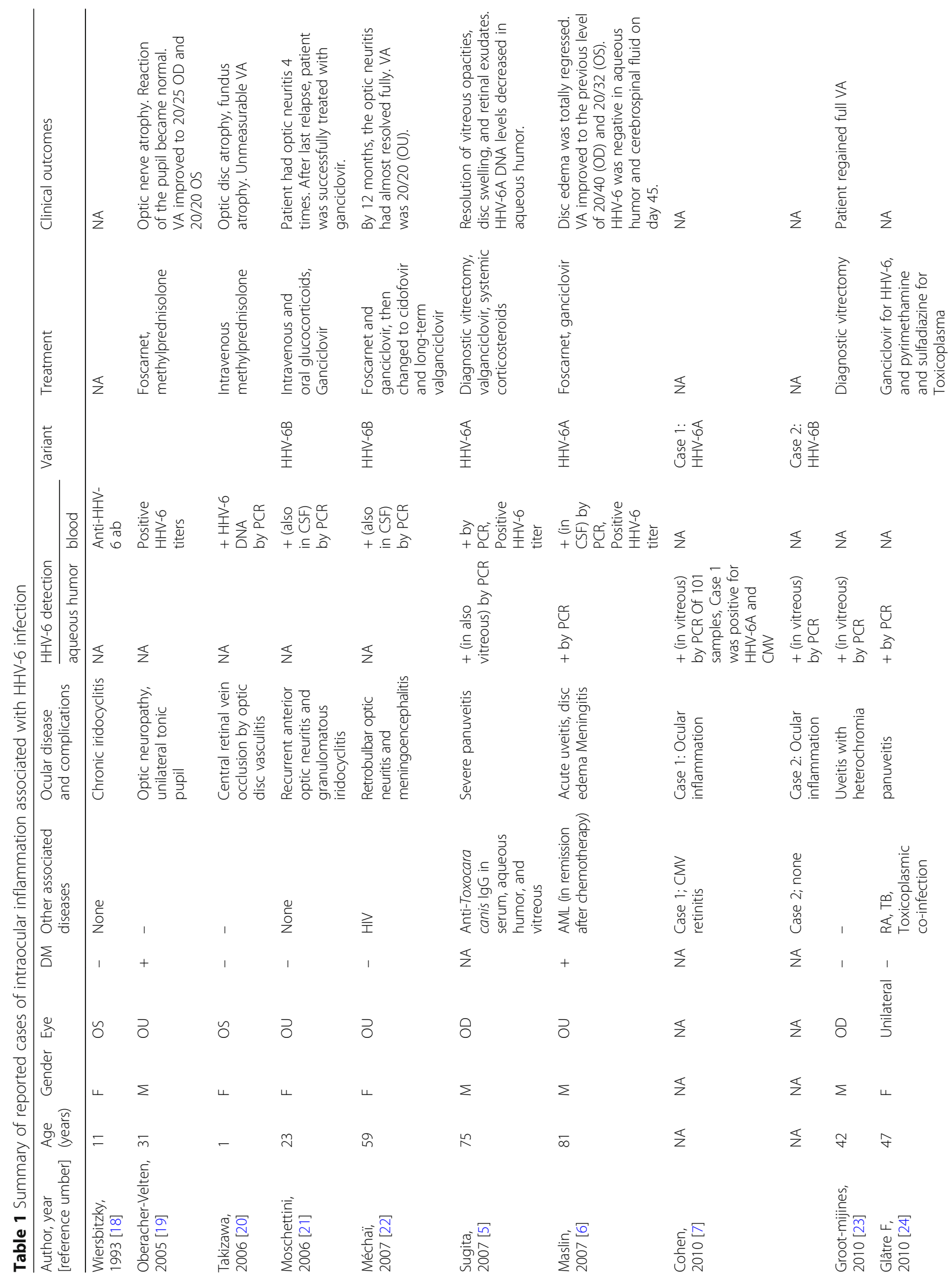




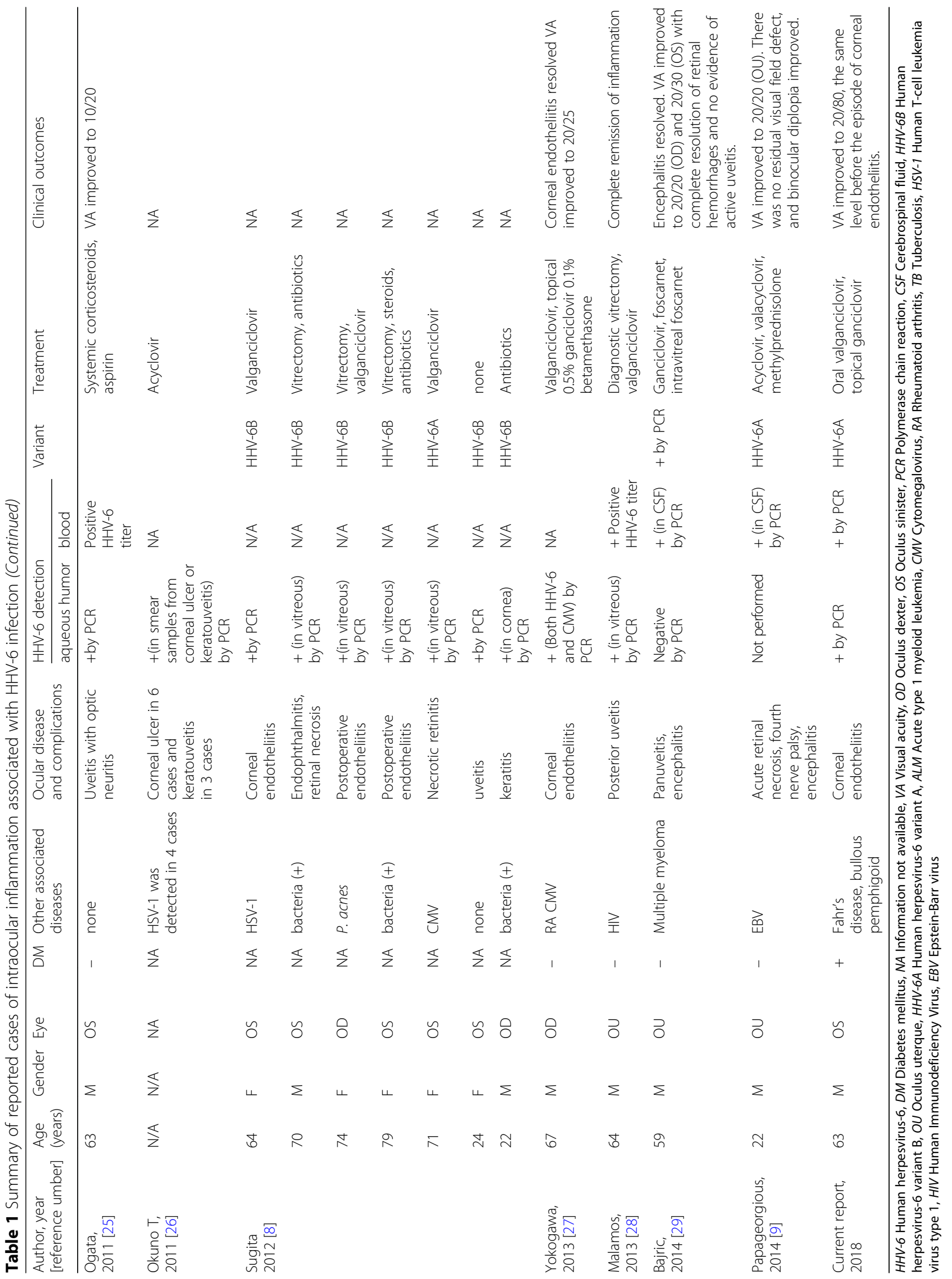


These two cases were treated with systemic steroids, but not antiviral drugs. There are currently no FDA-approval antiviral drugs for the treatment of HHV-6 infection [35]. However, foscarnet, ganciclovir, and cidofovir have shown efficacy against HHV-6 in vitro [36] and are currently used to treat HHV-6-related intraocular inflammation in clinical settings (Table 1).

In conclusion, we report the first case of HHV-6A corneal endotheliitis after intravitreal ranibizumab injection. HHV-6A endotheliitis can be a possible complication of intravitreal ranibizumab therapy. This may present as localized corneal edema with KPs, IOP elevation, and corneal endothelial damage. To confirm the diagnosis, multiplex strip PCR using ocular fluid can be used. The use of topical and/or systemic valganciclovir and ganciclovir is effective.

\section{Data sharing}

Data sharing is not applicable to this article as no datasets were generated during case report.

\section{Additional files}

Additional file 1: Corneal specular microscopy OS at the onset. The endothelium image was obtained by Konan Non-Con Robo Specular Microscope (Konan Medical, Inc., Hyogo, Japan). CD: endotheliam cell density, SD: standard deviation, CV: coefficient of value, 6A: hexagonal cell ratio, Pachy: central corneal thickness. Endothelial cell density was 1733 cells $/ \mathrm{mm}^{2}$. Corneal pachymetry of $597 \mu \mathrm{m}$ indicates mild edema. (JPG $72 \mathrm{~kb}$ )

Additional file 2: Corneal specular microscopy OS at 1-year follow-up. The endothelium image shows that endothelial cell density and corneal thickness are normal. (JPG $82 \mathrm{~kb}$ )

\section{Abbreviations \\ anti-VEGF: Anti-vascular endothelial growth factor; BCVA: Best corrected visual acuity; CMV: Cytomegalovirus; EBV: Epstein-Barr virus; HHV-6: Human herpesvirus-6; HHV-6A: Human herpesvirus-6 variant A; HHV-6B: Human herpesvirus-6 variant B; HIV: Human immunodeficiency virus; HSV: Herpes simplex virus; HTLV-1: Human T-cell leukemia virus type 1; IOP: Intraocular pressure; KP: Keratic precipitates; OD: Oculus dexter; OS: Oculus sinister; PCR: Polymerase chain reaction; PRN: Pro Re Nata regimen; rRNA: Ribosomal RNA; VZV: Varicella zoster virus}

\section{Acknowledgements}

Not applicable.

\section{Funding}

None.

\section{Availability of data and materials}

All data supporting the findings are contained within the manuscript.

\section{Authors' contributions}

$\mathrm{KI}$ was a major contributor in writing the manuscript. KM and $\mathrm{MO}$ contributed to the literature search and preparation of the manuscript and figures. TY and SS provided critical revision. YN, KO and IS were responsible for the clinical management of the patient. All authors read and approved the final manuscript.

\section{Ethics approval and consent to participate}

Ethics approval was obtained from the institutional review board, Medical Review Board of Gifu University Graduate School of Medicine and the study was adhered to the tenets of the Declaration of Helsinki. The written informed consent was obtained from the patient.

\section{Consent for publication}

The written consent for publish was obtained from the patient.

\section{Competing interests}

The authors declare that they have no competing interests.

\section{Publisher's Note}

Springer Nature remains neutral with regard to jurisdictional claims in published maps and institutional affiliations.

\section{Author details}

1Department of Ophthalmology, Gifu University Graduate School of Medicine, 1-1 Yanagido, Gifu-shi, Gifu 501-1194, Japan. 'Laboratory for Retinal Regeneration, Riken Center for Developmental Biology, Kobe, Japan. ${ }^{3}$ Department of Ophthalmology, Toho University Ohashi Medical Center, 2-22-36, Ohashi, Meguro-ku, Tokyo 153-8515, Japan.

Received: 26 April 2018 Accepted: 8 January 2019

Published online: 16 January 2019

\section{References}

1. Schirmer EC, Wyatt LS, Yamanishi K, Rodriguez WJ, Frenkel N. Differentiation between two distinct classes of viruses now classified as human herpesvirus 6. Proc Natl Acad Sci U S A. 1991;88:5922-6.

2. Razonable RR. Human herpesviruses 6,7 and 8 in solid organ transplant recipients. Am J Transplant. 2013;13:67-78.

3. Pantry SN, Medveczky PG. Latency, Integration, and Reactivation of Human Herpesvirus-6. Viruses. 2017;9. https://doi.org/10.3390/v9070194.

4. Khare MD. Human herpesvirus 6: its impact and influence on infectious diseases and their management. Expert Opin Pharmacother. 2001;2:213-21.

5. Sugita S, Shimizu N, Kawaguchi T, Akao N, Morio T, Mochizuki M. Identification of human herpesvirus 6 in a patient with severe unilateral panuveitis. Arch Ophthalmol. 2007;125:1426-7.

6. Maslin J, Bigaillon C, Froussard F, Enouf V, Nicand E. Acute bilateral uveitis associated with an active human herpesvirus-6 infection. J Inf Secur. 2007; 54:e237-40

7. Cohen II, Fahle G, Kemp MA, Apakupakul K, Margolis TP. Human herpesvirus 6-a, 6-B, and 7 in vitreous fluid samples. J Med Virol. 2010;82:996-9.

8. Sugita S, Shimizu N, Watanabe K, Ogawa M, Maruyama K, Usui N, et al. Virological analysis in patients with human herpes virus 6-associated ocular inflammatory disorders. Invest Ophthalmol Vis Sci. 2012;53:4692-8.

9. Papageorgiou E, Ch'ng S, Kulkarni A, Anwar S, Empeslidis T. Fourth cranial nerve palsy and bilateral acute retinal necrosis following human herpesvirus 6 infection of the central nervous system. Ocul Immunol Inflamm. 2014; 22:228-32.

10. Rayess N, Rahimy E, Shah CP, Wolfe JD, Chen E, DeCroos FC, et al. Incidence and clinical features of post-injection endophthalmitis according to diagnosis. Br J Ophthalmol. 2016;100:1058-61.

11. Falavarjani $K G$, Nguyen QD. Adverse events and complications associated with intravitreal injection of anti-VEGF agents: a review of literature. Eye (Lond). 2013;27:787-94.

12. Nakano S, Sugita S, Tomaru Y, Hono A, Nakamuro T, Kubota T, et al. Establishment of multiplex solid-phase strip PCR test for detection of 24 ocular infectious disease pathogens. Invest Ophthalmol Vis Sci. 2017:58:1553-9.

13. Khalili MR, Mehdizadeh M, Mehryar M. Herpetic epithelial keratitis after intravitreal injection of bevacizumab (avastin). Cornea. 2009;28:360-1.

14. Derham AM, Chen E, Bunya W, O'Malley RE. Bilateral herpetic keratitis after bilateral intravitreal bevacizumab for exudative macular degeneration. Cornea. 2017;36:878-9.

15. Kondo K, Kondo T, Okuno T, Takahashi M, Yamanishi K. Latent human herpesvirus 6 infection of human monocytes/macrophages. J Gen Virol. 1991:72:1401-8.

16. Luppi M, Barozzi P, Morris C, Maiorana A, Garber R, Bonacorsi G, et al. Human herpesvirus 6 latently infects early bone marrow progenitors in vivo. J Virol. 1999;73:754-9. 
17. Arbuckle JH, Pantry SN, Medveczky MM, Prichett J, Loomis KS, Ablashi D, et al. Mapping the telomere integrated genome of human herpesvirus $6 \mathrm{~A}$ and 6B. Virology. 2013:442:3-11.

18. Wiersbitzky S, Ratzmann GW, Bruns R, Wiersbitzky H. Reactivation in children of juvenile chronic arthritis and chronic iridocyclitis associated with human herpesvirus-6 infection. Padiatr Grenzgeb. 1993;31:203-5.

19. Oberacher-Velten IM, Jonas JB, Jünemann A, Schmidt B. Bilateral optic neuropathy and unilateral tonic pupil associated with acute human herpesvirus 6 infection: a case report. Graefes Arch Clin Exp Ophthalmol. 2005;243:175-7.

20. Takizawa Y, Hayashi S, Fujimaki T, Mizota A, Yokoyama T, Tanaka M, et al. Central retinal vein occlusion caused by human herpesvirus 6. J Pediatr Ophthalmol Strabismus. 2006:43:176-8.

21. Moschettini D, Franceschini R, Vaccaro NM, Cermelli C, Pezzini F, Balestrieri $M$, et al. Human herpesvirus-6B active infection associated with relapsing bilateral anterior optic neuritis. J Clin Virol. 2006;37:244-7.

22. Méchaï F, Boutolleau D, Manceron V, Gasnault J, Quertainmont Y, Brosseau JP, et al. Human herpesvirus 6-associated retrobulbar optic neuritis in an HIV-infected patient: response to anti-herpesvirus therapy and long-term outcome. J Med Virol. 2007;79:931-4.

23. de Groot-Mijnes JD, de Visser L, Zuurveen S, Martinus RA, Völker R, ten Dam-van Loon NH, de Boer JH, Postma G, de Groot RJ, van Loon AM, Rothova A. Identification of new pathogens in the intraocular fluid of patients with uveitis. Am J Ophthalmol. 2010;150:628-36.

24. Glâtre F, Rousseau E, Bacin F. Unilateral uveitis with HHV6-positive polymerase chain reaction in aqueous humor for an etanercept-treated woman: a case report. J Fr Ophthalmol. 2010;33:561-3.

25. Ogata N, Koike N, Yoshikawa T, Takahashi K. Human herpesvirus 6-associated uveitis with optic neuritis diagnosed by multiplex PCR. Jpn J Ophthalmol. 2011:55:502-5.

26. Okuno T, Hooper LC, Ursea R, Smith J, Nussenblatt R, Hooks JJ, et al. Role of human herpes virus 6 in corneal inflammation alone or with human herpesviruses. Cornea. 2011;30:204-7.

27. Yokogawa H, Kobayashi A, Yamazaki N, Sugiyama K. Identification of cytomegalovirus and human herpesvirus-6 DNA in a patient with corneal endotheliitis. Jpn J Ophthalmol. 2013;57:185-90.

28. Malamos P, Maselos S, Andrianopoulos K, Georgalas I, Chryssos G, Markomichelakis NN. Human herpes virus-6 as a cause of recurrent posterior uveitis in a HIV-positive patient. Retin Cases Brief Rep. 2013;7:131-3.

29. Bajric J, Smith WM. A case of bilateral human herpes virus 6 panuveitis with genomic viral DNA integration. J Ophthalmic Inflamm Infect. 2014;4:16.

30. Hall CB, Caserta MT, Schnabel KC, Long C, Epstein LG, Insel RA, et al. Persistence of human herpesvirus 6 according to site and variant: possible greater neurotropism of variant a. Clin Infect Dis. 1998;26:132-7.

31. Rothova A, Schneider M, de Groot-Mijnes JD. Human immunodeficiency virus-induced uveitis: intraocular and plasma human immunodeficiency virus-1 RNA loads. Ophthalmology. 2008;115:2062-4.

32. Ongkosuwito JV, Van der Lelij A, Bruinenberg M, Wienesen-van Doorn M Feron EJ, Hoyng CB, et al. Increased presence of Epstein-Barr virus DNA in ocular fluid samples from HIV negative immunocompromised patients with uveitis. Br J Ophthalmol. 1998;82:245-51.

33. Mitchell SM, Fox JD, Tedder RS, Gazzard BG, Lightman S. Vitreous fluid sampling and viral genome detection for the diagnosis of viral retinitis in patients with AIDS. J Med Virol. 1994;43:336-40.

34. Qavi HB, Xu B, Green MT, Lusso P, Pearson G, Ablashi DV. Morphological and ultrastructural changes induced in corneal epithelial cells by HIV-1 and HHV-6 in vitro. Curr Eye Res. 1996;15:597-604.

35. Phan TL, Lautenschlager I, Razonable RR, Munoz FM. HHV-6 in liver transplantation: a literature review. Liver Int. 2018:38:210-23.

36. Manichanh C, Grenot P, Gautheret-Dejean A, Debré P, Huraux JM, Agut H. Susceptibility of human herpesvirus 6 to antiviral compounds by flow cytometry analysis. Cytometry. 2000;40:135-40.

Ready to submit your research? Choose BMC and benefit from:

- fast, convenient online submission

- thorough peer review by experienced researchers in your field

- rapid publication on acceptance

- support for research data, including large and complex data types

- gold Open Access which fosters wider collaboration and increased citations

- maximum visibility for your research: over $100 \mathrm{M}$ website views per year

At $\mathrm{BMC}$, research is always in progress.

Learn more biomedcentral.com/submissions 